Ranzi concludes that the sexual cycle of marine annelids is influenced by a lunar factor, which cannot be the tide, because it occurs in the Mediterranean, where the tides are negligible, nor the light, because sunlight has no such effect. He suggests, therefore, that the influence of the moon is due to some action of unknown nature, not perceptible to our senses, but producing an effect on the sexual cycle of organisms. The facts would suggest that the effect is due to some peculiarity of moonlight which is absent from sunlight, and here is a question which bio-physicists might investigate. Moonlight is, I believe, polarised, but I do not know that any attempt has been made to test the effect of polarised light on the sexual cycle of living organisms.

35 Wavendon Avenue, W.4, March 14

1 NATURE, 129, 344, March 5, 1932

\& Pubblicazioni della Staz. Zool. di Napoli, vol. 11, Fascicolo 2, 1931.

\section{Stomatal Movement and Hydrogen Ion Concentration}

IN order to test the effect of the hydrogen ion concentration of the cell-sap on stomatal movement, experiments were made with the stomata of Tulipa, Scilla, Iris, and Tradescantia. It was found that the hydrogen ion concentration of the cell-sap of the guard-cells was approximately $4 \cdot 5$, while the epidermal cells were slightly less acid. The stripped epidermis was placed in buffer mixtures of known hydrogen ion concentration and left for two, six, twelve, and twenty-four hours respectively. The mixture used was the B.D.H. 'Universal Buffer Mixture'. For each time interval, one set was kept in the light and another in the dark for comparison. It was found that, in the case of Tulipa, the stomata were closed between $p \mathrm{H} 1$ and $p \mathrm{H} 5$, and at $p \mathrm{H} 6,7$, and 9 they were open, the maximum being at $p \mathrm{H}$ 7. In the dark the stomata were open at $p \mathrm{H} 5,6,7$, and 9 , the maximum being at $p H 5$. In the case of Scilla, the closure continued up to $p \mathrm{H} 6$ in light, to $p \mathrm{H} 5$ in the dark, with a maximum at $p \mathrm{H} 7$.

In order to avoid the possibly toxic effects of the buffer mixture, the experiments were repeated with solutions of carbon dioxide, of $p \mathrm{H}$ values $4 \cdot 4,4 \cdot 6$, $4 \cdot 8$, and $5 \cdot 0$. In all these, the stomata of Tulipa were open, the greatest opening being at 4.4 in light and $5 \cdot 0$ in dark. Scilla showed closure at $p \mathrm{H} \mathrm{4.4}$ and 5.0 in light and dark, opening at $4 \cdot 6$ and $4 \cdot 8$. Iris stomata were open throughout the whole range in light, and closed at 4.8 and 5.0 in dark, with a maximum opening at $4 \cdot 4$. Tradescantia showed a maximum opening at 4.4 in light, and closed at 4.4 in dark, with greatest opening at $5 \cdot 0$.

It is evident from this that the stomata of these forms are susceptible to changes in the $p \mathrm{H}$ value of the sap produced by carbon dioxide, and that the guard-cells respond by movement to these artificially produced changes. The experiments of which this is a preliminary account are still in progress, and it is intended to extend the observations to dicotyledons as well as to monocotyledons.

E. Phinip SMith.

University College, Dundee, March 3.

\section{A Virus Disease of Tobacco in South Africa}

AN obscure and destructive disease of tobacco has occurred for many years in the Stockenstrom district of the eastern Cape Province. It is becoming yearly more serious, and frequently causes total loss of both seed-beds and early plantings. Recent investigation has shown that it is a virus disease which, although bearing some resemblance to the 'ring-spot' described by Smith ${ }^{1}$ and Wingard, ${ }^{2}$ has important distinctive oharacters of its own.

A constant symptom of the disease is the sudden stoppage of apical growth and the stunting of leaves in process of formation. Leaf-spotting develops along various lines, but is usually of a 'ring-spot' or hieroglyphic type, often definitely related to the veins in a fern-leaf pattern. The youngest leaves show marked distortion and blistering, frequently accompanied by brilliant mottling. General chlorosis is usual in varieties of the Burley type, and is followed by discoloration of the stem in cortex and pith and by root decay associated with secondary organisms. Affected plants either die outright or survive through the season in a stunted condition. Some plants show a partial recovery, and after an interval make new growth from terminal or lateral shoots.

The disease can only very rarely be transmitted by needle puncture, but is readily induced by insertion of a diseased shoot (such as for grafting). It is, however, most easily transmitted by the feeding of a member of the thrips group (Frankliniella, species undetermined), and under field conditions this insect appears to be the sole vector. The green aphis common in seed-beds does not transmit the disease.

In the same locality, a tomato disease is prevalent which appears to be identical with the spotted wilt of Australia. ${ }^{3}$ Distinctive diseases of Datura Stramonium, Physalis (two species), and Nicandra physa. lodes also occur in the field and are transmitted by the same insect vector. From cross-inoculation studies in progress, there is every indication that all six diseases are caused by one and the same virus.

Department of Agriculture, E. S. MOORE.

Tobacco Laboratory

Balfour (Cape), South Africa, Feb. 1.

1 Smith, Ann. Appl. Biol., 16, 382; 1929.

2 Wingard, J. Agri. Res., 37, $127 ; 1928$.

3 Samuel, Bald, and Pittman, Bull. 44, Coun. Sci. Ind. Res. Australia, 1930. See also NATURE, 128,$494 ; 1931$.

\section{Oviposition of Telenomus nigrocoxalis Aschm. (Ghalcididæ)}

Telenomus nigrocoxalis, a hymenopterous eggparasite of the Coconut butterfly in British Guiana (Brassolis sophorce L.), was observed under magnification on an egg-mass of the host. After a careful inspection and tapping of the eggs with her antennæ, the female decides upon a particular egg and penetrates the shell dorso-laterally with a few strokes of the ovipositor, which is inserted into a minute puncture. The female remains in this position for about four minutes. Now and then a male stops to tap the female on the head and thorax with his antennæ.

One female, probably an old one, was unable to extricate her ovipositor and, after about ten minutes in this awkward position, collapsed and lay apparently dead between the eggs. Presently a male happened upon her, and immediately showed the greatest concern for the unfortunate female. His agitated movements in attempting to revive the female and distracted behaviour were quite touching. A speck of water, accidentally left with my brush on an adjacent egg before this incident occurred, was now noticed apparently for the first time. By means of one of his antennæ the male applied some of this water to the prostrate female.

This movement was repeated many times, but without great success, for there was no sign of life yet and the ovipositor was still held by the egg. Another male appeared on the scene and immediately took in

No. 3258, VoL. 129] 